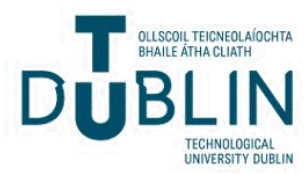

Technological University Dublin

ARROW@TU Dublin

\section{Barley for Brewing: Characteristic Changes during Malting, Brewing and Applications of its By-Products}

\author{
Mahesh Gupta \\ Technological University Dublin, mahesh.gupta@tudublin.ie \\ Nissreen Abu-Ghannam \\ Technological University Dublin, nissreen.abughannam@tudublin.ie \\ Eimear Gallaghar \\ Teagasc, ,Ashtown Food Research Centre, eimear.gallaghar@teagasc.ie
}

Follow this and additional works at: https://arrow.tudublin.ie/schfsehart

Part of the Food Processing Commons

\section{Recommended Citation}

Gupta, M., Abu-Ghannam, N., \& Gallaghar, E. (2010). Barley for Brewing: Characteristic Changes during Malting, Brewing and Applications of its By-Products. Comprehensive Reviews in Food Science and Food Safety, 9, 318-328. DOI: 10.1111/j.1541-4337.2010.00112.x

This Article is brought to you for free and open access by the School of Food Science and Environmental Health at ARROW@TU Dublin. It has been accepted for inclusion in Articles by an authorized administrator of ARROW@TU

Dublin. For more information, please contact

arrow.admin@tudublin.ie, aisling.coyne@tudublin.ie, gerard.connolly@tudublin.ie.

Funder: FIRM

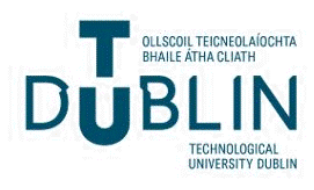




\section{COMPREHENSIVE REVIE E WS IN FOOD SCIENCE AND FOOD SAFETY}

\section{Barley for Brewing: Characteristic Changes during Malting, Brewing and Applications of its By-Products}

Mahesh Gupta, Nissreen Abu-Ghannam, and Eimear Gallaghar

\section{Importance of Barley Grain}

Barley (Hordeum vulgare, vulgare L.) is a highly adaptable cereal grain that is produced in climates ranging from sub-Arctic to subtropical. It ranks 5th among all crops in dry matter production in the world today (129 million metric tons, 2002 to 2005 mean). Historically, barley has been an important food source in many parts of the world, including the Middle East, North Africa, and northern and eastern Europe (mainly Iran, Morocco, Ethiopia, Finland, England, Germany, Denmark, Russia, and Poland), and in Asia (Japan, India, Tibet, and Korea) (Chatterjee and Abrol 1977; Newman and Newman 2006). At present, only $2 \%$ of barley is used for human food (Baik and Ullrich 2008).

MS 20091266 Submitted 12/18/2009, Accepted 2/8/2010. Authors Gupta and Abu-Ghannam are with School of Food Science and Environmental Health, Dublin Inst. of Technology, Cathal Brugha St., Dublin 1, Ireland. Author Gallaghar is with Teagasc, The Ashtown Food Research Centre, Ashtown, Dublin 15, Ireland. Direct inquiries to author Abu-Ghannam (E-mail: nissreen.abughannam@dit.ie).
Barley grain is an excellent source of soluble and insoluble dietary fiber (DF) and other bioactive constituents, such as vitamin E (including toco-tri-enols), B-complex vitamins, minerals, and phenolic compounds. $\beta$-Glucans, the major fiber constituents of barley, have been implicated in lowering plasma cholesterol, improving lipid metabolism, and reducing glycemic index. The effectiveness of barley $\beta$-glucans in food products for lowering blood cholesterol has been documented in a number of studies (Newman and others 1989; Behall and others 2004). Barley is a rich source of tocols, including tocophenols and toco-tri-enols, which are known to reduce serum low-density lipoprotein cholesterol through their antioxidant action (Qureshi and others 1986). Whole grains are known for their fiber content, and therefore lower energy density, and as a source of vitamins and mineral components, both of which may increase satiety and reduce energy intake (Slavin 2003). In Western countries, pearled barley, whole, flaked, or ground is used in breakfast cereals, stews, soups, porridge, bakery flour blends, and baby foods. In Middle Eastern and North African countries, barley is pearled and ground, and used in soups, flat bread, and porridge (Bhatty 1993). Newman 
and Newman (2006) have presented a recent concise review of the history of barley foods. Barley flour, prepared from pearled grain through hammer milling or roller milling, can easily be incorporated into wheat-based products, including bread, cakes, cookies, noodles, and extruded snack foods (Newman and Newman 1991). Newman and others (1990) prepared barley flour muffins of acceptable quality, which were only slightly inferior in volume, density, and moisture to wheat flour muffins. Some cookie and brownie recipes can also be substituted with $100 \%$ barley flour and maintain acceptable quality and flavor. Regular and waxy barley flours were successfully extruded in the production of expanded snack foods or cereals using a modified laboratory single-screw extruder (Baik and others 2004). In modern time, barley is used in the production of alcoholic beverages, in particular beer. Recently, however, interest in barley as a food grain is reviving due to heightened consumer awareness of good nutrition and increased interest in foods and food ingredients enriched in DF (Izydorczyk and Dexter 2008). Recently, barley has gained popularity due to the functional properties of its bioactive compounds in barley-based different healthy food products. Germination is a process in which physical modification of endosperm is carried out to increase the bioactive compounds (Madhujith and Shahidi 2007). Worldwide, the greatest use of barley is for malting purposes, most specifically for the brewing industry. However, in recent years, there has been a growing interest in incorporating barley into the human diet because it is wholesome, readily available, and relatively inexpensive (Keenan and others 2007).

\section{Characteristics of Malting Barley Grain}

Barley grain that is clean, bright yellow-white, plump, thinhulled, medium-hard, and uniform in size is generally suitable for food uses and preferred for pearling (Pomeranz 1974). Grain hardness is an important characteristic of barley because it determines the pearling and subsequent end-use quality of barley. Malting barley varieties are usually soft, whereas nonmalting varieties are usually hard. Psota and others (2007) also reported significant relationships between hardness of barley grain as assessed using the particle size index and hot water extract of malt as well as the malt quality index of barley malt. Other structural and compositional characteristics of barley endosperm could contribute to grain hardness, including proteins, starch, $\beta$ glucan, and their interactions, and packing during grain filling (Henry 1988). Generally, sound barley grain has a bright lightyellow or off-white color. Discolored barley grain often develops undesirable flavors when malted and has poor germination energy and vigor ( $\mathrm{Li}$ and others 2003). The grain color of barley can vary from light yellow to purple, violet, blue, and black, which is mainly caused by the level of anthocyanins in the hull, pericarp, and/or aleurone layer. Highly colored types are also receiving attention for applications in functional foods due to their antioxidant properties (Satue-Gracia and others 1997; Nam and others 2006; Philpott and others 2006). However, most of the barley that is produced possesses bright, light yellow grain color, which is generally preferred for malting, brewing, and food purposes.

Whole barley grain consists of about $65 \%$ to $68 \%$ starch, $10 \%$ to $17 \%$ protein, $4 \%$ to $9 \% \beta$-glucan, $2 \%$ to $3 \%$ free lipids, and $1.5 \%$ to $2.5 \%$ minerals (Czuchajowska and others 1998; Izydorczyk and others 2000; Quinde and others 2004). Total DF ranges from $11 \%$ to $34 \%$ and soluble DF from $3 \%$ to $20 \%$ (Fastnaught 2001). Pearling reduces the contents of insoluble fiber, protein, ash, and free lipids (Quinde and others 2004). On the other hand, hulled barley is preferred to hull-less barley for malting and brewing because of the contribution of the hull to beer flavor and as a filtering aid during brewing (Burger and La-Berge 1985). The amy- lose content of barley starch varies from $0 \%$ to $5 \%$ in waxy, $20 \%$ to $30 \%$ in normal, and up to $45 \%$ in high-amylose barley (Bhatty and Rossnagel 1997). Mixed linked (1-3), (1-4)- $\beta$-D-glucans constitute approximately $75 \%$ of the barley endosperm cell walls together with $20 \%$ arabinoxylans and protein. Both $\beta$-glucans and arabinoxylans determine wort viscosity and beer filtration rates (Stewart and others 2000), and form a barrier for hydrolytic enzymes attacking starch and protein within the cell walls causing potential health benefits such as prevention of constipation, reduction in risk of colorectal cancer (Bingham 1990; Faivre and Bonithon-Kopp 1999), lowering of blood cholesterol, and controlling diabetes management (Gallagher and others 1993; Frost and others 1999). Barley endosperm protein is rich in prolamin storage proteins (hordeins) and has moderate nutritional quality (Newman and McGuire 1985). High-lysine barley mutants, which contain $2 \%$ to $3 \%$ greater lysine than normal lysine types could provide high-quality, protein-enriched barley grains for the human diet (high lysine content of 5\% to $6 \%$ compared to $3 \%$ as normal ones) (Ullrich and Eslick 1978).

A large number of parameters have been proposed to define malting quality. It is also a fact that the texture of the endosperm influences the malt modification process by affecting water uptake and consequently enzyme synthesis and movement within the endosperm (Chandra and others 1999). Andersson and others (1999) studied the variation and correlation between chemical and physical characteristics of barley samples including kernel hardness, but found only a low correlation between kernel hardness and physical and chemical grain properties. One another factor as potential influence of sulfur (S) on barley malting quality has so far received little attention. Sulfur deficiency has been shown to affect the composition of proteins in barley grain, with depletion in the S-rich B hordein and the high-molecularweight $(\mathrm{HMW}) \mathrm{D}$ hordein and an increase in the $\mathrm{S}$-poor $\mathrm{C}$ hordein (Shewry 1993). The malting of hull-less barley, however, presents a number of challenges due to differences in chemical and physical characteristics.

\section{Malting and Mashing of Barley Grain}

Barley is the primary cereal used in the production of malt in the world. Two types of barley are frequently used for the malting process: 6 - and 2-row. Two-row barley produces malt with a large extract, lighter color, and less enzyme content than the 6row type (Broderick 1977). From the different quality parameters reported in the literature, hot-water extract (HWE), kernel size fractions, kernel weight, $\beta$-glucan and protein contents, malting losses, friability, $\alpha$-amylase activity, viscosity, and soluble nitrogen ratio (SNR) are common assays used to test the quality of barley mutant (Fox and others 2003). In addition, fast hydration and germination are necessary traits of barley for good malting quality (Ulonska and Baumer 1976; Briggs 1998). During malting, barley undergoes an incomplete natural germination process that involves a series of enzyme degradations of barley kernel endosperm. As a result of this enzyme degradation, endosperm cell walls are degraded, and starch granules are released from the matrix of the endosperm in which they are embedded. These structural changes and biochemical degradations of the endosperm components are referred to as endosperm modification (Gunkel and others 2002). Malting is defined as the controlled germination of cereals, to ensure a given physical and biochemical change within the grain, which is then stabilized by grain drying. Three process steps are necessary to ensure that these changes occur: (1) steeping, to ensure good absorption of water by the grain (from $12 \%$ to at least $40 \%$ of moisture); (2) germination, to maintain embryo growth, enzyme synthesis and a limited endosperm breakdown; and (3) kilning, to ensure product stability. 


\section{CRFSFS: Comprehensive Reviews in Food Science and Food Safety}

Different kernel properties have been identified as factors affecting water uptake during steeping of barley, for example, endosperm structure, starch content, protein content, and cell wall properties (Ogushi and others 2002). Loosely packed endosperm gives soft (mealy) structure and facilitates better moisture and enzyme movements in the endosperm. Thus, a mealy endosperm is more easily degraded by hydrolytic enzymes during malting (Swanston and others 1995). On the other hand, starch granule size and distribution, amylose, amylopectin, $\beta$-glucan, and arabinoxylan content have also been proposed as factors in affecting the hardness of the endosperm (Dombrink and Knutson 1997; Tohno-Oka and others 2004). As a result of the malting process, there is an increase in enzyme activity, soluble protein, and breakdown of starch into simple sugars, along with development of the typical color and flavor (Hoseney 1994). The final moisture content of malt is approximately 35 to $40 \mathrm{~g} / \mathrm{kg}$, being a highly hygroscopic product. Mashing is a key step in the beer production process. During mashing, enzymatic degradation of the polysaccharides present in the malt takes place. Fermentable carbohydrates are produced from the degradation of the polysaccharide starch. Such carbohydrates are converted into alcohol in the fermentation step of the beer manufacturing. Nonstarch polysaccharides also degrade during mashing into smaller chain carbohydrates. Different enzymes catalyze all the involved reactions. Because the activity of the different enzymes is highly dependent on temperature, the manipulation of such variable is the main control mechanism for the mashing process (Hardwick 1995).

\section{Various Factors Affecting Brewing Process of Barley \\ Grain}

\section{Properties of antioxidants}

Antioxidants are not evenly distributed in barley grains. Salomonsson and others (1980) indicated that $p$-coumaric acid was present in the lowest amount in the center of the barley kernel and rapidly increased toward the outer layers, such as lignified husk (Maillard and Berset 1995), whereas Goupy and others (1999) have indicated that phenolic acids were mainly present in the aleurone layer and endosperm. The content of ferulic acid is highest in the cell walls of the aleurone layer, which is rich in arabinoxylans. Maillard and Berset (1995) have separated and identified trans-ferulic acid, trans- $p$-coumaric acid, and cis-ferulic acid from barley and malt. The natural antioxidants in cereals may act as free radical scavengers, reducing agents, potential complexes of pro-oxidant metals, and singlet oxygen quenchers (Zielinski 2002). Moreover, many of the natural antioxidants present in barley exhibit a wide range of biological effects, including antibacterial, antiviral, anti-inflammatory, anti-allergic, and antithrombotic effects, and may also be involved in vasodilatory actions (Cook and Sammon 1996). Polyphenols identified in barley include anthocyanins, flavonols, phenolic acids, catechins, and proanthocyanidins (Goupy and others 1999). There are more than 50 proanthocyanidins reported in barley, and they include oligomeric and polymeric flavan-3-ol, catechin (c), and gallocatechin (gc). The most abundant proanthocyanidins in barley are dimeric proanthocyanin B3 and procyanidin B3. Major trimers include T1 $(\mathrm{gc}-\mathrm{gc}-\mathrm{c}), \mathrm{T} 2(\mathrm{gc}-\mathrm{C}-\mathrm{c}), \mathrm{T} 3(\mathrm{c}-\mathrm{gc}-\mathrm{c})$, and T4 or procyanidins $\mathrm{C} 2(\mathrm{C}-\mathrm{C}-\mathrm{C})$ (Friedrich and others 2000). Phenolic compounds in cereal grains exist in the free, soluble esters or conjugates, and insoluble-bound forms (Adom and Liu 2002). Antioxidants are generally thought to play a significant role in malting and brewing due to their ability to delay or prevent oxidation reactions and oxygen free radical reactions. Antioxidants such as sulfites, formaldehyde, or ascorbate, can be added into the brew- ing process to improve beer flavor stability. About $80 \%$ of phenolic compounds present in beer are derived from barley malt, and the remaining come from hops (Goupy and others 1999). Those phenolic compounds in malting barley include polyphenols (benzoic and cinnamic acid derivatives), flavonoids, proanthocyanidins, tannins, and amino phenolic compounds (Hernanz and others 2001; Bonoli and others 2004), all of which are known to inhibit nonenzymatic lipid peroxidation and widely recognized as having important antioxidant and antiradical properties. Therefore, the presence of the natural antioxidants in malting barley and screening of malting barley variety with the highest level of radical scavengers seems very important to produce beers with high levels of antioxidant activity (Maillard and others 1996).

\section{Arabinoxylans and $\boldsymbol{\beta}$-glucan content}

Arabinoxylans $(\mathrm{AX})$ consist of a linear-chain backbone of $\beta$-Dxylopyranosyl (Xylp) residues linked through (1-4) glycosidic linkages. $\alpha$-L-Arabinofuranosyl (Araf) residues are attached to some of the Xylp residues at O-3, O-4, and/or at both $\mathrm{O}-2,3$ positions, resulting in 4 structural elements in the molecular structure of arabinoxylans: monosubstituted Xylp at O-2 or O-3, disubstituted Xylp at O-2, 3, and unsubstituted Xylp (Figure 1; Gruppen and others 1993; Izydorczyk and Biliaderis 1995; Vinkx and others 1995). A unique feature of arabinoxylans is the presence of hydroxycinnamic acids and ferulic and $p$-coumaric acids, esterified to O-5 of Araf linked to O-3 of the xylose residues (Smith and Hartley 1983). The content of arabinoxylans in barley also depends on genetic and environmental factors (Fleury and others 1997; Izydorczyk and others 2000; Holtekjølen and others $2007)$ but appears to be less variable than that of $\beta$-glucans. Compared to other grains, the amount of arabinoxylans in barley is similar to that in wheat $(5.8 \%)$, but higher than in oats $(2.7 \%$ to $3.5 \%)$, sorghum $(1.8 \%)$, or rice $(2.6 \%)$ (Izydorczyk and Biliaderis 2007). Fleury and others (1997) reported that the amount of arabinoxylans in the hull-less barley $(3.37 \%$ to $4.30 \%)$ was significantly lower than in the 2 - or 6 -rowed $(5.41 \%$ to $6.42 \%)$ covered barley, and linked the differences to the absence of hulls in the former. Six-rowed barley cultivars generally contain slightly higher levels of arabinoxylans than 2-rowed cultivars (Fleury and others 1997). The presence of the waxy gene in barley does not affect the content of arabinoxylans to the same extent as that of $\beta$ glucans. In view of the importance of nonstarch polysaccharides in the malting of barley and in subsequent steps in the brewing process, including the possible influence of residual cell walls on the rate of wort separation during mashing process (Han and Schwarz 1996). But undermodified malts, the fact that arabinoxylans cannot be degraded sufficiently, may cause many problems such as low extract yield, high wort viscosity, decrease of filtration rate, and haze formation in brewing (Coote and Kirsop 1976). It has been found that other large molecules such as AX, proteins, and polyphenols were also associated with reduced beer filtration, in particular microfiltration. In fact, it has been reported that the amount of $\mathrm{AX}$ in commercial beer is approximately 10 times greater than that of $\beta$-glucan (Schwarz and Han 1995). The enzymes that degrade $A X$ are often produced late in the germination process (Banik and others 1997), and high levels of AX can survive through the brewing into the final beer. Some AX are solubilized from the cell walls but are not extensively degraded by endogenous enzymes during malting (Voragen and others 1987). Malt extracts can contain high levels of $A X$ and cause difficulties associated with the filtration of viscous extracts may significantly deteriorate the performance of the brewing processes (Bamforth 1985).

Mixed linkage (1-3,1-4)- $\beta$-D-glucans, commonly known as $\beta$ glucans, are linear homopolymers of D-glucopyranosyl (Glcp) residues linked mostly via 2 or 3 consecutive $\beta$-(1-4) linkages 

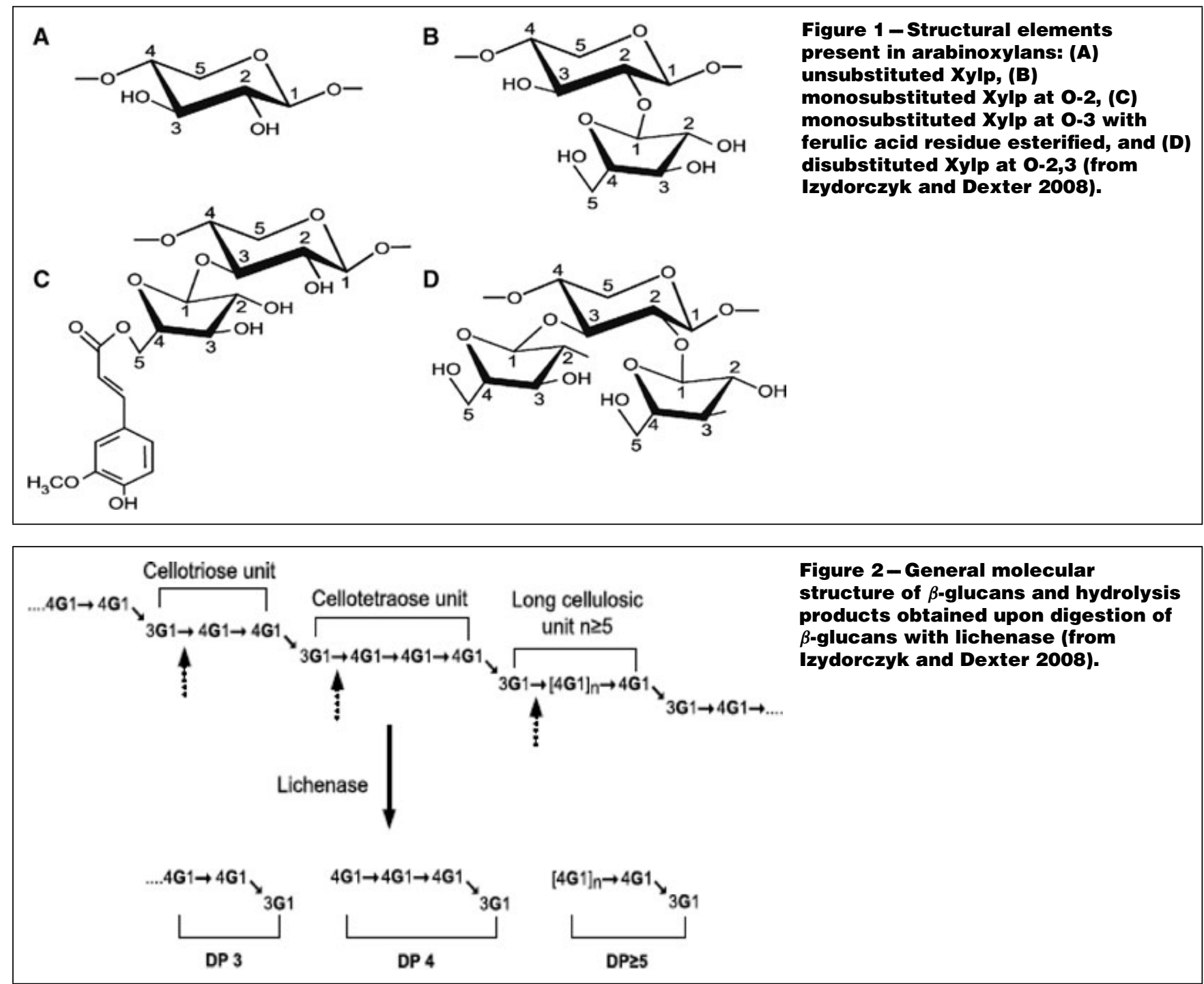

(Figure 2) that are separated by a single $\beta-(1-3)$ linkage (Cui and others 2000). The changes of both $(1-3,1-4)-\beta$-D-glucan (referred to as $\beta$-glucan) content and (1-3, 1-4)- $\beta$-D-glucan4-glucanohydrolase (referred to as $\beta$-glucanase, E.C.3.2.1.73) activity in barley during malting are important for malt producers, which is closely associated with malt yield and quality. $\beta$-Glucanase is a cell wall polysaccharide, which accounts for approximately $70 \%(\mathrm{w} / \mathrm{w})$ of the endosperm cell in barley (Forrest and Wainwright 1977; Jeraci and Lewis 1989). Compared to other grains, barley contains a relatively high concentration of $\beta$-glucan, a viscous and fermentable DF, therefore may be highly satiating (Marciani and others 2001). In the brewing industry, a high content of $\beta$-glucan in barley may lead to insufficient degradation of cell walls, which in turn hinders the diffusion of enzymes, germination, and the mobilization of kernel reserves, and hence reduces malt extract. Residual $\beta$-glucan may also lead to highly viscous wort, giving rise to a filtration problem in the brewery, and it may participate in maturing of beer, causing chill haze (Bamforth 1982). The degradation of endosperm cell walls and subsequent changes in $\beta$-glucan levels during malting are, to a great extent, related to $\beta$-glucanase activity, which depolymer- izes $\beta$-glucan (Etokakpan 1993). Therefore, better malting performance is expected to be associated with lower levels of $\beta$-glucan in grains and higher levels of $\beta$-glucanase in malt. Historically, reduced beer filtration efficiency has been mainly attributed to $\beta$-glucan in the brewing process. $\beta$-Glucan may increase the viscosity of beer by forming gels, consisting primarily of HMW $\beta$-glucan molecules (Home and others 1999). Barley has gained popularity due to the functional properties most likely antioxidant and radical scavenging activity due to its bioactive compounds such as $\beta$-glucan, arabinoxylan, oligosaccharides, tocols, and phenolic compounds (Baik and Ullrich 2008).

\section{Protein in barley grain}

Proteins are among barley components that are essential for the quality of malt and beer. First, high-protein contents decrease available carbohydrates, with a negative influence on the brewing process (Peltonen and others 1994; Fox and others 2002) and second, proteolysis (protease hydrolysis producing amino acids and peptides from hordeins) during malting and mashing is necessary for yeast metabolism (Moll 1979). Finally, soluble proteins are important in beer head retention and stability. The 
protein content in barley grains represents, approximately, $8 \%$ to $15 \%$ of its total mass. Hordeins are the most abundant proteins $(40 \%$ to $50 \%)$ found in a barley grain (Osman and others 2002). In addition to hordeins, other proteins have been identified, including albumins, glutelins (globulins), friabilin, enzymes, and serpins (Finnie and others 2002; Fox and others 2002; Osman and others 2003; Boren and others 2004). Barley hordeins are divided into 5 groups based on their electrophoretic mobilities and amino acid compositions: the $\mathrm{B}$ and $\mathrm{C}$ hordeins $(70 \%$ to $80 \%$ and $10 \%$ to $20 \%$ of the hordein fraction, respectively) and D, Z, and $\gamma$ hordeins (less than $5 \%$ of the total hordein fraction) (Shewry 1993; Tatham and Shewry 1995). The B hordeins can be subdivided into B1, B2, and B3 subtypes (Skerritt and Janes 1992). Furthermore, a distinction is made between the sulfur-rich ( $\mathrm{B}$ and $\gamma$ hordeins), the sulfur-poor (C hordeins), and HMW prolamins (D hordeins) (Shewry 1993; Tatham and Shewry 1995). It has been hypothesized by Moonen and others (1987) that in barley, HMW subunits form a backbone, which binds low-molecular-weight (LMW) subunits through disulfide bridges to form a gel-like aggregate. The majority of beer protein lies in the 10 to $40 \mathrm{kDa}$ size range (Leiper and others 2003). Mostly, the origin of HMW protein is malted barley (Hughes and Baxter 2001). Some beer proteins appear to have no function in beer except their contribution to mouthfeel, flavor, texture, body, color, and nutritional value (Leiper and others 2003; Osman and others 2003). Protein Z, LTP1 (lipid transfer protein), and other proteins present in beer have been associated with foam formation and/or stabilization (Evans and Sheehan 2002; Perrocheau and others 2005). Protein $Z$ has also been related to beer haze (Curioni and others 1995). During malting, barley proteins are in part degraded to amino acids and small peptides by a range of proteolytic enzymes (Baxter 1981; Enari and Sopanen 1986; Jones 2005a, 2005b). Brewer's spent grain (BSG), the main by-product of the brewing industry, is rich in proteins and DF (Mussatto and others 2006). Identification of protein in the malt and beer samples by polyacrylamide gel electrophoresis or high-performance liquid chromatography has become a routine laboratory test in grain segration in malt houses and in barley breeding programs.

\section{Hydrolysis of starch}

Rapid hydrolysis of starch to the fermentable carbohydrates glucose, maltose, and maltotriose is an important aspect of brewing. Starch hydrolysis is carried out by the malt enzymes $\alpha$-amylase, $\beta$-amylase, limit dextrinase, and $\alpha$-glucosidase (Manners 1985). Limit dextrinase is responsible for hydrolyzing the $(1 \rightarrow 6)-\alpha$ glucosidic branch points in LMW branched dextrins formed by the action of $\alpha$ - and $\beta$-amylase on starch components (Manners and others 1970). Starch granules can be encapsulated by a rigid protein matrix or by cell walls (Weurding and others 2001). $\alpha$ Amylase can solubilize both amorphous and crystalline regions (Lauro and others 1993) of starch granules attacking the $(\alpha-4)$ linkages of starch producing oligosaccharides. $\beta$-Amylase also attacks $(\alpha-4)$-linkages from the nonreducing ends of amylose and amylopectin molecules (Bamforth and Quain 1989; Lewis and Young 1995). A range of fermentable sugars is produced from the action of these enzymes on starch during the mashing process. These include glucose, sucrose, fructose, and mainly maltose and also some LMW dextrins (Slack and Wainwright 1980; Lauro and others 1993). Starch $\alpha$-amylolysis depends also on the particle size of starch granules (Colonna and others 1988). Large starch granules gelatinize earlier than small ones at high temperatures, despite the fact that the small granules have a slightly lower gelatinization enthalpy and a higher surface-to-volume ratio than the large granules, and hence one would expected them to gelatinize earlier than the large ones (Soulaka and Morrison 1985; Morrison and others 1994). The rate of hydrolysis may be influenced by both the surface features and internal structure of starch granules (Li and others 2003). Fermented wort and beer, however, contains appreciable levels of branched dextrin (Enevoldsen and Schmidt 1973) and suggesting that there is limited hydrolysis by limit dextrinase during the mashing process. Results to date suggest that the enzyme is readily solubilized from malt, but most of it is in an inactive form that requires "activation" to release, in full, the enzymic activity (MacGregor and others 1994a, 1994b; Sissons 1996). Other enzymes in the grist, such as limit dextrinase, may also contribute to the fermentable sugar profile. These enzyme activities are profoundly influenced by such a high mashing temperature as $65^{\circ} \mathrm{C}$. $\beta$-Amylase, in particular, is rapidly denatured at temperatures above $55^{\circ} \mathrm{C}$. $\alpha$-Amylase is rather more stable and remains active for over an hour at $65^{\circ} \mathrm{C}$ (Muller 1991).

\section{Role of Enzymes in Malting and Brewing of Barley Grain}

The conversion of barley into beer represents mankind's oldest and most complex example of applied enzymology. Indeed, historically some of the most significant advances in enzymology have been linked to the world of brewing, such as Eduard Buchner's extraction of enzymes from brewing yeast (Buchner 1897) and Adrian Brown's kinetic analysis of invertase (Brown 1902). In determining the factors that a bearing on the quality of beer, brewers have learned not only how the endogenous enzymes contribute to issues such as fermentability, filterability, foam, clarity, flavor, so on, but also how to take advantage of exogenous enzymes. There are 3 primary "enzyme reactor" stages in the conversion of barley to beer (Bamforth 2006): barley kernel, mash tun, and the yeast cell. Only in one of these, the mash tun, is considered a "typical" enzyme reactor and has been extensively researched (Boulton and Quain 2001).

More than 40 endopeptidases have been identified in malt, broadly classified into cysteine-, metallo-, aspartic-, and serineproteinases (Jones 2005a). There are also exo-peptidases classifiable into carboxypeptidases (Mikola and others 1971) and amino peptidases (Sopanen and Mikola 1975). A substantive reason for the limited action of the endo-peptidases in mashing is the presence of inhibitor proteins (Jones 2005b). Principal among such inhibitors are lipid transfer proteins that block the cysteineproteinases (Jones 2005b). Jones and Budde (2005) suggest that $32 \%$ of the soluble protein in malt is already in the ungerminated barley form, $46 \%$ is released in malting and the rest solubilized in mashing. It was shown that over the $\mathrm{pH}$ range 5 to 6.6 , the proteolytic activity of malt can vary more than 7 -fold (Jones and Budde 2003). Various factors may come together in causing the release of the enzyme in an active form during malting (Buttimer and Briggs 2000). It was recently suggested that serine-proteinases have a key role to play here (Schmitt and Marinac 2008). The least investigated of the endogenous starch-degrading enzymes in malted barley is $\alpha$-glucosidase, although it has been claimed to be 2 nd only to $\alpha$-amylase for its importance in starch degradation during malting (Sun and Henson 1991). However, the enzyme is thermolabile and likely to be of limited significance during mashing (Muslin and others 2000). Low-calorie beers, so-called Light, are the biggest selling style of beers and the exaggerated scares about "bad carbs" in beer (Bamforth 2005) led to the advent of "low carb beers." For such products, glucoamylase and pullulanase are of great utility in dealing with the dextrins surviving because of the limited action of limit dextrinase (Goode and others 2005).

\section{By-Products Obtained during Malting and Brewing}

The brewing industry generates relatively large amounts of byproducts and wastes spent grain, spent hops, and yeast being the most common. However, as most of these are agricultural 
Barley brewing and by-product applications...

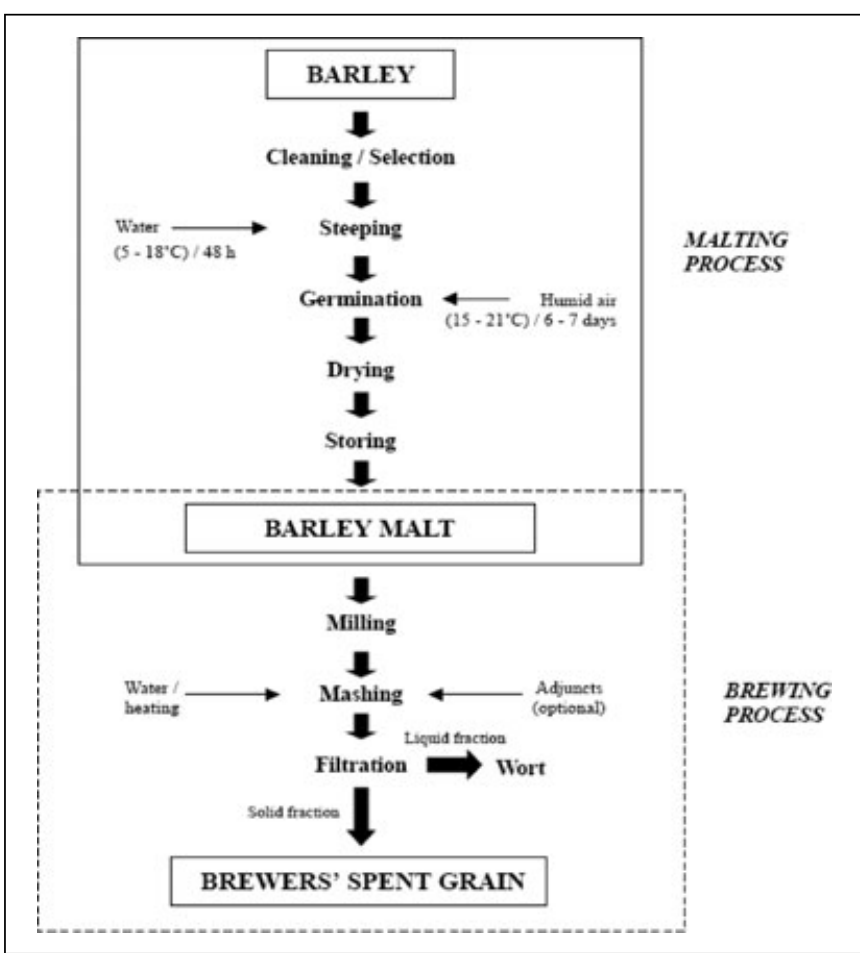

Figure 3-Schematic representation of the process to obtain BSG from natural barley (from Mussatto and others 2006).

products, they can be readily recycled and reused. Thus, compared to other industries, the brewing industry tends to be more environmentally friendly (Ishiwaki and others 2000). Spent grain is the most abundant brewing by-product, corresponding to approximately $85 \%$ of total by-products generated (Reinold 1997). According to Townsley (1979) spent grain accounts, on average, for $31 \%$ of the original malt weight, representing approximately
$20 \mathrm{~kg}$ per $100 \mathrm{~L}$ of beer produced (Reinold 1997). BSG is available at low or no cost throughout the year and is produced in large quantities not only by large but also small breweries. In the brewery, malted barley is milled, mixed with water in the mash tun, and the temperature of mash slowly increased from 37 to $78^{\circ} \mathrm{C}$ to promote enzymatic hydrolysis of malt constituents (Figure 3). This enzymatic conversion stage (mashing) produces a sweet liquid known as wort. The insoluble, undergraded part the malted barley grain is allowed to settle to form a bed in the mash tun and the sweet wort filtered through it (lautering) (Linko and others 1998; Dragone and others 2002). Figure 3 is a schematic representation of the process resulting in the production of brewers' spent grain from barley grain. BSG may consist of the residues from malted barley, or those from malted barley and adjuncts (nonmalt sources of fermentable sugars), such as wheat, rice, or maize added during mashing (Reinold 1997). The chemical composition of BSG varies according to barley variety, harvest time, malting and mashing conditions, and the quality and type of adjuncts added in the brewing process (Huige 1994; Santos and others 2003); but in general, BSG is considered as a lignocellulosic material rich in protein and fiber, which account for around $20 \%$ and $70 \%$ of its composition, respectively. Microscopic examination shows the presence of numerous fibrous tissues from the surface layers of the original barley grain (Figure 4). The main components of these fibrous tissues are arabinoxylan, lignin (a polyphenolic macromolecule), and cellulose (a linear homopolymer of glucose units). Analyses of BSG by Santos and others (2003) indicated that besides fiber, $24.2 \%$ protein, $3.9 \%$ lipid, and $3.4 \%$ ash are present in oven-dried BSG. The protein, apparent starch, nonstarch polysaccharide composition fraction is different in BSG from pilot scale trials of malting barley of different varieties. Protein and fiber are highly concentrated in spent grain because most of the barley starch is removed during mashing (Kissel and Prentice 1979).

Minerals, vitamins, and amino acids are also found in BSG. The mineral elements include calcium, cobalt, copper, iron, magnesium, manganese, phosphorus, potassium, selenium, sodium, and sulfur, all in concentrations lower than $0.5 \%$ each (Pomeranz and Dikeman 1976; Huige 1994). The vitamins include (in ppm): biotin (0.1), choline (1800), folic acid (0.2), niacin

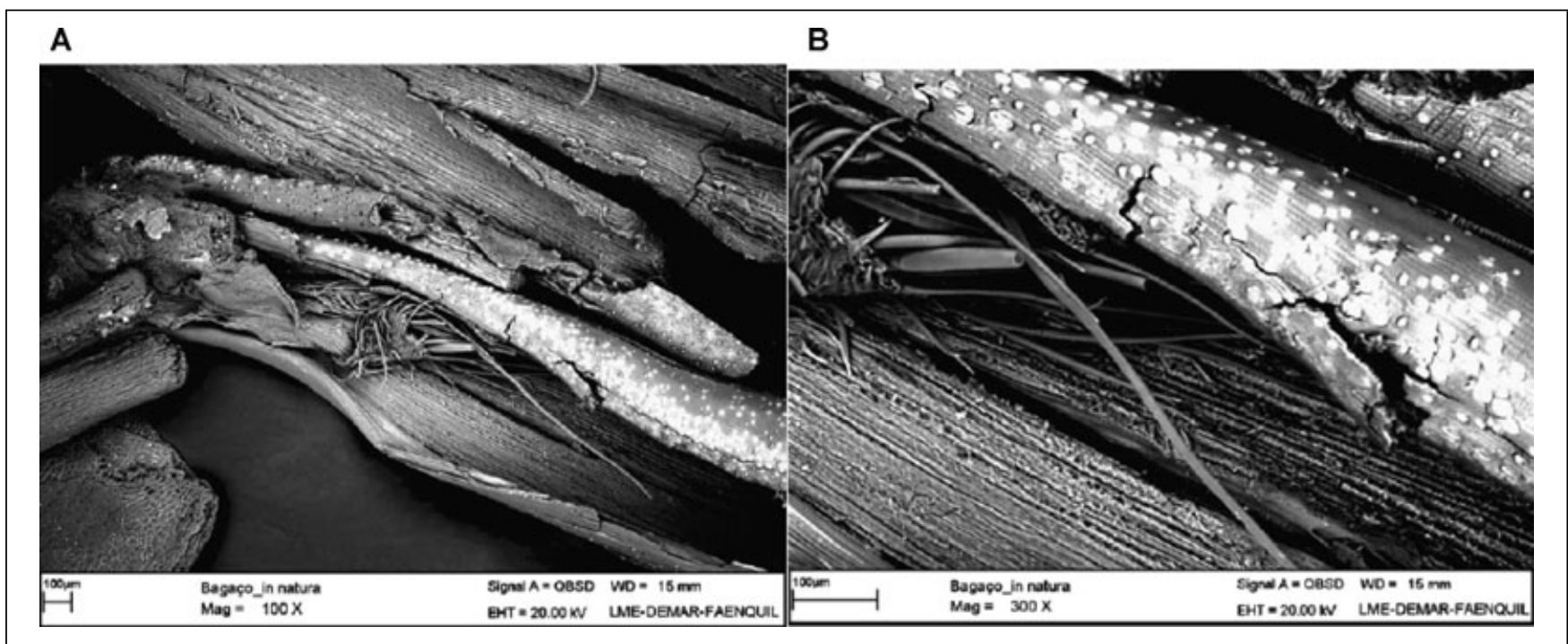

Figure 4-Scanning electron microscopy of BSG particles. (A) Magnification 100-fold and (B) magnification 300-fold (from Mussatto and others 2006). 
(44), pantothenic acid (8.5), riboflavin (1.5), thiamine (0.7), and pyridoxine (0.7); protein-bound amino acids include leucine, valine, alanine, serine, glycine, glutamic acid, and aspartic acid in the largest amounts, and tyrosine, proline, threonine, arginine, and lysine in smaller amounts. Cystine, histidine, isoleucine, methionine, phenylalanine, and tryptophan also present in minor quantity (Huige 1994).

\section{Novel Food Applications of the By-Products of Malting and Brewing of Barley}

BSG can be employed either as a wet residue, shortly after separation from the wort at lautering, or as a dried material (Townsley 1979; Ozturk and others 2002). According to Huige (1994), BSG is an excellent feed ingredient for ruminants because it can be combined with inexpensive nitrogen sources, such as urea, to provide all the essential amino acids. In addition to its high nutritional value, BSG is reported to promote increased milk production without affecting animal fertility (Sawadogo and others 1989; Belibasakis and Tsirgogianni 1996a, 1996b; Reinold 1997). When BSG was incorporated into the diet of cows, milk yield, milk total solid content, and milk fat yield were increased. At the same time, blood plasma concentrations of glucose, total protein, albumin, urea, triglycerides, cholesterol, phospholipids, sodium, potassium, calcium, phosphorus, and magnesium were not affected (Belibasakis and Tsirgogianni 1996a, 1996b). Kaur and Saxena (2004) evaluated BSG as a replacement for rice bran in a fish diet and observed that fish fed with a diet containing rice bran and 30\% BSG had a superior body weight gain when compared with fish fed with rice bran only.

\section{Food applications}

BSG, the residue left after separation of the wort during the brewing process (Santos and others 2003), is rich in cellulose and noncellulosic polysaccharides, mainly arabinoxylans (Mandalari and others 2005) as well as protein and $\beta$-glucan (Mussatto and others 2006). Approximately, 3.4 million metric ton of spent grains from the brewing industry are produced in the European Union every year (Eurostat data 2005). These plant-derived waste co-products are known to contain significant amounts of valuable components, which remain unexploited waste in the current processes. Because of its high moisture and fermentable sugar content, BSG becomes an environmental problem after a short time (7-10 d). It has a strong potential for being recycled and used as a cheap source of fiber that may provide a number of benefits when incorporated into human diets such as for the prevention of certain diseases including cancer, gastrointestinal disorders, diabetics, and coronary heart disease (Aman and others 1994; Jacobs and others 1998). Because of its relatively low cost and high nutritive value, BSG has been evaluated for the manufacture of flakes, whole wheat bread, biscuits, and aperitif snacks. However, BSG is too granular for direct addition to food and must first be converted to flour (Hassona 1993; Miranda and others 1994a, 1994b; Ozturk and others 2002). A high-protein flour prepared from BSG was successfully incorporated into a number of bakery products, including breads, muffins, cookies, mixed grain cereals, fruit and vegetable loaves, cakes, waffles, pancakes, tortillas, snacks, doughnuts, and brownies (Townsley 1979; Huige 1994). Nevertheless, there are some limitations in the use of flour as a protein additive or as a partial replacement for presently used flours, due to its color and flavor. BSG is brownish in color when moist and thus can only be used in off-white products, such as light-colored cookies, cakes, bread, or spaghetti that are made entirely from whole meal flour. Moreover, because of alterations in the flavor and physical properties (for example, texture) of the final products, only relatively small quantities $(5 \%$ and $10 \%$ ) can be incorporated (Townsley 1979; Hassona 1993; Miranda and

\section{Table 1 - Properties of BSG flour in foods.}

\section{Ease of blending}

2. Calorie content is approximately half that of most cereal flours $(27.0 \mathrm{MJ} / \mathrm{kg})^{\mathrm{a}}$

3. High water absorption capacity

4. Provides valuable minerals such as $\mathrm{Ca}, \mathrm{P}, \mathrm{Fe}, \mathrm{Cu}, \mathrm{Zn}$, and $\mathrm{Mg}$

5. Low fat absorption (beneficial for batters and coating)

6. Uniform tan color, bland flavor, and mildly roasted aroma

7. High fiber content as arabinoxylans $(21.8 \%)^{\text {b }}$

8. High protein content $(24 \%)^{\text {b }}$

\section{Data from Huige (1994)}

a Data from Okamoto and others (2002).

bData from Kanauchi and others (2001).

others 1994a, 1994b). Prentice and D'Appolonia (1977) made high fiber bread containing BSG and evaluated its consumer acceptance. The results of their study showed that incorporation of BSG increase the nutritional and consumer acceptance level. In another study, BSG was finely milled and heat-treated at 45, 100 or $150{ }^{\circ} \mathrm{C}$ and replaced white flour in a conventional bread formula at $5 \%, 10 \%$, and $15 \%$ levels. Bread containing heattreated $\left(45{ }^{\circ} \mathrm{C}\right) \mathrm{BSG}$, at $5 \%$ and $10 \%$ flour replacement levels was accepted favorably (Hassona 1993). Some properties of BSG flour in foods are shown in Table 1. The ingestion of BSG or derived products provides benefits for health, and is associated with increased fecal weight, accelerated transit time, increased cholesterol and fat excretion, and decrease in gallstones (Fastnaught 2001). Incorporation of spent grain in rat diets prevented an increase in plasma total lipids as well as of cholesterol (Hassona 1993; Ishiwaki and others 2000).

BSG has been converted to a new protein-rich fibrous foodstuff by separating the husk fraction by milling and sieving. The product, germinated barley foodstuff (GBF), contains the aleurone layer, scutellum, and germ fractions of germinated barley, and is composed mainly of noncellulosic polysaccharides and glutamine-rich protein and is low in lignin (Kanauchi and Agata 1997). GBF feeding is considered a potentially new attractive prebiotic treatment in patients with ulcerative colitis (Kanauchi and others 2001; Bamba and others 2002). Furthermore, GBF has a high water-holding capacity compared with other water-insoluble DF sources, and this feature might contribute to a conspicuously high stool-forming ability in the colon (improvement of bowel movement) (Bamba and others 2002). GBF also appears to be safe and well tolerated. On the whole, BSG is a cheap source of protein and fiber that may provide a number of benefits when incorporated in human diets. For this reason, it is a potentially important food ingredient, especially in developing countries where poor malnutrition exists.

The incorporation of BSG into food products as a source of DF has been addressed in the literature such as its incorporation into flour-mixed breads (Prentice and D'Appolonia 1977; Finley and Hanamoto 1980; Kawka and others 1999), cookies (Kissel and Prentice 1979; Ozturk and others 2002), and animal and fish feed (Batajoo and Shaver 1994; Dung and others 2002). There is a growing interest to increase the DF content of extruded products by supplementing with wheat bran, corn bran, oat bran, wheat fiber, sugar beet fiber, and $\beta$-glucans (Lue and others 1991; Gaosong and Vasanthan 2000; Mendonca and others 2000; Martianez-Tomea and others 2004; Yanniotis and others 2007). These types of products are potentially healthier, due to the increased fiber, and can be used as a prophylactic product. The extrusion cooking of high-fiber cereal product under low temperature and shear conditions affects digestibility of starch, DF components, and phytate in the human stomach and small intestine (Sandberg and others 1986). Thus, BSG could be 
a cheap source of protein and fiber that may provide a number of benefits when incorporated in human diets (Mussatto and others 2006). However, reference searches indicate that very little attention on the incorporation of BSG into extruded products has been published. Extrusion is a continuous cooking and shaping (forming) process designed to give unique physical and chemical functionality to food materials. Raw food ingredients undergo many order-disorder transitions, such as breakdown of starch granules, protein denaturation, and complex formation between lipids and amylose during extrusion. Extrusion-processing also controls the water activity of ingredients. It is therefore useful in producing shelf-stable foods and, more important, in producing a variety of items like snack foods and breakfast cereals. BSG is rich in complex carbohydrates and protein so it can be used for the extrusion processing to make various snacks.

\section{Other applications}

BSG is rich in polysaccharides and also in associated proteins and minerals and thus is a substrate of high biotechnological value. In this respect, several possible applications of BSG in biotechnological processes have been evaluated. BSG has been successfully used as a substrate for cultivating species of Pleurotus, Agrocybe, and Lentinus (Schildbach and others 1992). BSG had good biological efficiency and high nutritional value as a substrate for Pleurotus ostreatus, especially when water-rinsed BSG was used (Wang and others 2001). It has been proposed that BSG favors the growth of these mushrooms not only due to its high protein content (Townsley 1979), but also to its high moisture content and physical properties such as particle size, volume weight, specific density, porosity, and water holding capacity (Wang and others 2001).

Cereal brans with compositions and physical structures comparable with BSG have been used extensively as substrates for the production of commercial enzymes in so-called koji or solid-state fermentations (Chou and Rwan 1995; Aikat and Bhattacharyya 2000; Sangeetha and others 2004). For this reason, BSG has also been evaluated as an alternative substrate for enzyme production. BSG is an efficient substrate for xylanase production by a Streptomyces isolate from Brazilian cerrado soil (Nascimento and others 2002), and for the production of xylanase and feruloyl esterase by Streptomyces avermitilis (Bartolome and others 2002, 2003). $\alpha$-Amylase production by Bacillus subtilis (Duvnjak and others 1983) and Bacillus licheniformis (Okita and others 1985) cultivated on BSG has also been reported.

The reuse of BSG in the brewing process could be attractive from the point of view of brewery economics. Roberts (1976) showed that a BSG extract (a spent grain pressing concentrate) was effective as an antifoaming agent in the fermenter; in addition, hop utilization was improved and the properties of the final beer were not affected when the BSG extract was added. Addition of untreated BSG to wort enhanced the fermentation performance of yeast (Kado and others 1999), but the flavor and taste of the resulting beer was not satisfactory. However, addition of a neutralized acid extract of BSG to wort enhanced yeast performance and produced beer of quality equal to that of beer fermented without spent grain. BSG sequentially pretreated with $\mathrm{HCl}$ and $\mathrm{NaOH}$ solutions has been evaluated as a carrier for immobilizing brewer's yeast (Saccharomyces uvarum) (Branyik and others 2001, 2002, 2004a, 2004b).

The cell walls of the barley grain residues in BSG are rich in cellulose and noncellulosic polysaccharides, in particular arabinoxylans, but also some residual (1-3, $1-4)-\beta$-glucan. The cell wall polysaccharides can be degraded into their corresponding constituents by hydrolytic procedures (hydrothermal, enzymatic, or acidic). Upon hydrolysis, cellulose yields glucose and the noncellulosic polysaccharides xylose, mannose, galactose, and ara- binose, as well as acetic and hydroxycinnamic acids (Palmqvist and Hahn-Hagerdal 2000; Mussatto and Roberto 2004) and some of these products are of industrial significance as precursors of food-grade chemicals or as energy sources in microbial fermentations. Hydrothermal hydrolysis (autohydrolysis by acetic acid released from its esterified form on the arabinoxylans) treatment of BSG with water at $150{ }^{\circ} \mathrm{C}$ for 60 and 120 min gave a wide variety of arabino-oligoxylosides with different structural features. The arabino-furanosyl side-branches on the xylan backbone are readily hydrolyzed and are easily removed by this treatment. The higher thermal sensitivity of the arabinose components compared to xylose, leads to release of large amounts of free arabinose when the temperature of the process is increased; and to major amounts of xylo-oligosaccharides. Hydroxycinnamic acids (ferulic and p-coumaric acids) present in BSG have potential uses in the food industry (Bartolome and Gomez-Cordoves 1999; Bartolome and others 2003). Bartolome and others (1997) used an esterase from Aspergillus niger to release ferulic acid from BSG and observed that $3.3 \%$ of the total ferulic acid was released, but in the presence of a xylanase from Trichoderma viride increased the extraction up to $30 \%$ (Bartolome and others 2003).

\section{Future Considerations}

Barley is one of the most ancient crops, and it has evolved through domestication to today as a major world crop based on acreage and production. It has great potential to reclaim some of its prominence as a food grain, largely due to its high nutritional value. Starch is a unique component of barley grain that gives physical properties to food products, but barley also contains high contents of protein and $\beta$-glucan. However, because human consumption of barley and barley-containing food products has been insignificant as compared to other cereal grains, the development of new processes and food products has been neglected and there has been little effort to define quality requirements for food uses. The significance of $\beta$-glucan and tocols for human nutrition is well known, but little is known about the functional properties of $\beta$-glucan for making food products. Some of the traits preferred for specific food applications are known through investigations on incorporating barley into wheat-based food products. On the other hand, the functional properties of $\beta$-glucans in food processing and end-use quality, with the exception of malting and brewing are little known. Much of the more recent interest in the use of $\beta$-glucans in food systems has stemmed from their use as a functional DF. Innovative ways are being developed to bring DF into new appealing high-fiber products that contribute to the recommended DF intake (Natl. Academy of Sciences 2002). The development of new techniques to use this agro-industrial byproduct is of great interest due to the large volumes of spent grain produced. More research is required to understand how the gel protein is disaggregated during malting and how the aggregates form during mashing.

Increasing efforts are being directed towards the re-use of agro-industrial by-products, from both economic and environmental standpoints. Brewer's spent grain (BSG) is an abundant by-product that can be obtained from brewing companies worldwide. However, in spite of all the possible applications described, its use is still limited, being basically used as animal feed or simply as a land fill. BSG can be considered as an attractive adjunct for human food. BSG has been used, for example, to make protein-enriched breads, which could be very useful in the poorer regions of the world where food is scarce. On the other hand, considering that carbohydrates are the major components, more attention should be paid to its conversion into soluble and fermentable sugars. Currently, a number of addedvalue bioproducts such as organic acids, amino acids, vitamins, 


\section{CRFSFS: Comprehensive Reviews in Food Science and Food Safety}

ethanol, butanediol, among others, are produced by fermentation using glucose or xylose as substrates. But there is little information about the residual barley proteins present in BSG and their interactions with other BSG polymers. A consequential benefit of the use of industrial by-products such as BSG is as raw materials in various food applications. In addition, from an environmental viewpoint, the elimination of industrial by-products represents a solution to disposal and pollution problems.

\section{References}

Adom KK, Liu RH. 2002. Antioxidant activity of grains. J Agric Food Chem 50:6182-7.

Aikat K, Bhattacharyya BC. 2000. Optimization of some parameters of solid state fermentation of wheat bran for protease production by a local strain of Rhizopus oryzae. Acta Biotech 20:149-59.

Aman P, Zhang JX, Hallmans G, Lundin E. 1994. Excretion and degradation of dietary fiber constituents in mileostomy subjects consuming a low fiber diet with and without brewer's spent grain. J Nutr 124:359-63.

Andersson AAM, Elfverson C, Andersson R, Regner S, Aman P. 1999. Chemical and physical characteristics of different barley samples. J Sci Food Agric 79:979-86.

Baik BK, Ullrich SE. 2008. Barley for food: characteristics, improvement, and renewed interest-Critical review. J Cereal Sci 30:1-10.

Baik BK, Powers J, Nguyen LT. 2004. Extrusion of regular and waxy barley flours for production of expanded cereals. Cereal Chem 81:94-99.

Bamba T, Kanauchi O, Andoh A, Fujiyama Y. 2002. A new prebiotic from germinated barley for nutraceutical treatment of ulcerative colitis. J Gastro Hepato 17:818-24.

Bamforth CW. 1982. Barley $\beta$-glucans: their role in malting and brewing. Brew Dig 3:22-35. Bamforth CW. 1985. Biochemical approaches to beer quality. J Inst Brew 91:154-60.

Bamforth CW. 2005. Beer, carbohydrates and diet. J Inst Brew 111:259-64.

Bamforth CW. 2006. Scientific principles of malting and brewing. St Paul, Minn.: American Society of Brewing Chemists.

Bamforth CW, Quain DE. 1989. Enzymes in brewing and distilling. In: Palmer GH, editor Cereal science and technology. 1st ed. UK: Aberdeen Univ. Press, p 326-66.

Banik M, Li CD, Langridge P, Fincher GB. 1997. Structure, hormonal regulation, and chromosomal location of genes encoding barley (1-4)- $\beta$-xylan endohydrolases. Mol Gen Genet 253:599-608.

Bartolome B, Gomez-Cordoves C. 1999. Barley spent grain: release of hydroxycinnamic acids (ferulic and p-coumaric acids) by commercial enzyme preparations. J Sci Food Agric 79:435-9.

Bartolome B, Faulds CB, Williamson G. 1997. Enzymic release o-ferulic acid from barley spent grain. J Cereal Sci 25:285-8.

Bartolome B, Santos M, Jiménez JJ, Del-Nozal MJ, Gómez-Cordovés C. 2002. Pentoses and hydroxycinnamic acids in brewers' spent grain. J Cereal Sci 36:51-8.

Bartolome B, Gomez-Cordoves C, Sancho Al, Dıez N, Ferreira P, Soliveri J, Copa-Patiño JL. 2003. Growth and release of hydroxycinnamic acids from brewer's spent grain by Streptomyces avermitilis CECT 3339. Enz Micro Tech 32:140-4.

Batajoo KK, Shaver RD. 1994. Impact of nonfiber carbohydrate on intake, digestion and milk production by dairy cows. J Dairy Sci 77:1580-8.

Baxter ED. 1981. Hordein in barley and malt. A review. J Inst Brew 87:173-6.

Behall KM, Scholfield DJ, Hallfrisch J. 2004. Diets containing barley significantly reduce lipids in mildly hypercholesterolemic men and women. Am J Clin Nutr 80:1185-93.

Belibasakis NG, Tsirgogianni D. 1996a. Effects of dried citrus pulp on milk yield, milk composition and blood components of dairy cows. Anim Feed Sci Tech 60:87-92.

Belibasakis NG, Tsirgogianni D. 1996b. Effects of wet brewers grains on milk yield, milk composition and blood components of dairy cows in hot weather. Anil Feed Sci Tech 57:175-81.

Bhatty RS. 1993. Physicochemical properties of roller-milled barley bran and flour. Cereal Chem 70:397-402

Bhatty RS, Rossnagel BG. 1997. Zero amylose lines of hull-less barley. Cereal Chem 74:190-1.

Bingham MK. 1990. Field detection and implications of mercury in natural gas. SPE Prod Engg 5:120-4.

Bonoli M, Verardo V, Marconi E, Caboni MF. 2004. Antioxidant phenols in barley (Hordeum vulgare L.) flour: comparative spectrophotometer study among extraction methods of free and bound phenolic compounds. I Agric Food Chem 52:5195-200.

Boren M, Larsson H, Falk A, Jansson C. 2004. The barley starch granule proteome-internalized granule polypeptides of the mature endosperm. Plant Sci 166:617-26.

Boulton C, Quain D. 2001. Brewing yeast and fermentation. Oxford, UK: Blackwell Science Ltd.

Branyik T, Vicente A, Cruz JM, Teixeira JA. 2001. Spent grains-a new support for brewing

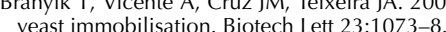

Branyik T, Vicente A, Cruz JM, Teixeira JA. 2002. Continuous primary beer fermentation with brewing yeast immobilized on spent grains. J Inst Brew 108:410-5.

Branyik T, Vicente A, Cruz JM, Teixeira JA. 2004a. Physicochemical surface properties of brewing yeast influencing their immobilization onto spent grains in a continuous reactor. Biotech Bioeng 88:84-93.

Branyik T, Vicente AA, Kuncová G, Podrazky O, Dostálek P, Teixeira JA. 2004b. Growth model and metabolic activity of brewing yeast biofilm on the surface of spent grains: biocatalyst for continuous beer fermentation. Biotech Prog 20:1733-40.

Briggs DE. 1998. Malts and malting. Blackie Academic \& Professional, London Barley. In Gaul H, editor. Proceedings of the 3rd Intl. Barley Genetics Symposium, Barley Genetics III. Garching. Munchen: Verlag Karl Thiemig. p 579-93.

Broderick H. 1977. El Cervecero en la Practica: Un Manual para la Industria Cervecera. 2nd ed. Wisconsin, U.S.A.: Assn. de Maestros Cerveceros de las Americas. p 29-52.
Brown A. 1902. Enzyme action. J Chem Soc 81:373-88.

Buchner E. 1897. Alkoholische Gährung ohne Hefezellen (vorläufige Mittheilung). Berichte der Deutschen Chemischen Gesellschaft 30:117-24.

Burger WC, La-Berge DE. 1985 Malting and Brewing quality. In: Rasmusson DC, editor. Barley. Madison, WI: American Society of Agronomy.

Buttimer ET, Briggs DE. 2000. Mechanisms of the release of bound beta-amylase. J Inst Brew 106:83-94.

Chandra GS, Proudlove MO, Baxter ED. 1999. The structure of barley endosperm-an important determinant of malt modification. J Sci Food Agric 79:37-46.

Chatterjee SR, Abrol YP. 1977. Protein quality evaluation of popped barley grains (Sattu). J Food Sci Tech 14:247-50.

Chou C, Rwan J. 1995. Mycelial propagation and enzyme production in koji prepared with Aspergillus oryzae on various rice extrudates and steamed rice. J Ferment Bioeng 79:509-12

Colonna P, Buléon A, Lemarié F. 1988. Action of Bacillus subtilis $\alpha$-amylase on native wheat starch. Biotech Bioeng 31:895-904.

Cook NC, Sammon S. 1996. Flavonoids, chemistry, metabolism, cardioprotective effects and dietary sources. Nutr Biochem 7:66-77.

Coote N, Kirsop BH. 1976. A haze consisting largely of pentosan. J Inst Brew 82:34

Cui W, Wood PJ, Blackwell B, Nikiforuk J. 2000. Physicochemical properties and structural characterization by two-dimensional NMR spectroscopy of wheat $\beta$-Dglucans - comparison with other cereal $\beta$-D-glucans. Carbohydr Poly 41(3):249-58.

Curioni A, Pressi G, Furegon L, Peruffo ADB. 1995. Major proteins of beer and their precursors in barley: electrophoretic and Immunological studies. J Agric Food Chem 43:2620-6.

Czuchajowska Z, Klamczynski A, Paszczynska B, Baik BK. 1998. Structure and functionality of barley starches. Cereal Chem 75:747-54.

Dombrink MA, Knutson CA. 1997. A study of maize endosperm hardness in relation to amylose content and susceptibility to damage. Cereal Chem 74:776-80.

Dragone G, Almeida e Silva JB, Silva DP, Santos L. 2002. Elaboracion de cervezas en Brasil: proceso dealtas densidades. Industria de Alimentos 5:44-46.

Dung NNX, Manh LH, Uden P. 2002. Tropical fibre sources for pigs-digestibility, digesta retention and estimation of fibre digestibility in vitro. Anil Feed Sci Tech 102:109-24

Duvnjak Z, Budimir A, Suskovic J. 1983. Effect of spent grains from beer production on production of $\alpha$-amylase by Bacillus subtilis 21C. Prehrambeno-Tehnoloska Revija 21:97-101. Enari TM, Sopanen T. 1986. Mobilisation of endospermal reserves during the germination of barley centenary review. J Inst Brew 92:25-31.

Enevoldsen BS, Schmidt F. 1973. Dextrins in brewing. II. Distribution of oligo- and megaoligosaccharides during mashing in wort and in beer. In: Proceedings of the 14th Congress, European Brewing Convention. p 135-48.

Etokakpan OU. 1993. Enzymatic degradation and nature of the endosperm cell-walls of germinating sorghums and barley. J Sci Food Agric 61:389-93.

Eurostat data. 2005. http://www.repro-food.net/english/benefits.htm.

Evans DE, Sheehan MC. 2002. Do not be fobbed off: the substance of beer foam-a review.

J Am Soc Brew Chem 60:47-57.

Faivre J, Bonithon-Kopp C. 1999. Diets, fibers and colon cancer. Adv Exp Med Biol 72:199-206.

Fastnaught CE. 2001. Barley fibre. In: Cho S, Dreher M, editors. Handbook of dietary fibre New York: Marcel Dekker. p 519-42.

Finley JW, Hanamoto MM. 1980. Milling and baking properties of dried brewers' spent grains. Cereal Chem 57:166-8.

Finnie C, Melchior S, Roepstorff P, Svensson B. 2002. Proteome analysis of grain filling and seed maturation in barley. Plant Phy 129:1308-19.

Fleury MD, Edney M J, Campbell LD, Crow GH. 1997. Total, water-soluble and acid-soluble arabinoxylans in western Canadian barleys. Can J Plant Sci 77(2):191-6.

Forrest IS, Wainwright T. 1977. The mode of binding of $\beta$-glucans and pentosans in barley endosperm cell walls. J Inst Brew 83:279-86.

Fox GP, Onley-Watson K, Osman A. 2002. Multiple linear regression calibrations for barley and malt protein based on the spectra of hordein. J Inst Brew 108:155-9.

Fox GP, Panozzo JF, Li CD, Lance RCM, Inkerman PA, Henry RJ. 2003. Molecular basis of barley quality. Aust J Agric Res 54:1081-101.

Friedrich W, Eberhardt A, Galensa R. 2000. Investigation of proanthocyanidins by HPLC with electrospray ionization and spectrophotometry. Eur Food Res Technol 211:56-64.

Frost G, Leeds AA, Dore CJ, Maderios S, Brading S, Dornhurst A. 1999. Glycaemic index as a determinant of serum, cholesterol concentration. Lancet 353:1045-8.

Gallagher DD, Hassel CA, Lee KJ, Gallagher CM. 1993. Viscosity and fermentability as attributes of dietary fibre responsible for hypocholestrolemic effects in hamsters. I Nut 123:244-52.

Gaosong J, Vasanthan T. 2000. Effect of extrusion cooking on the primary structure and water solubility of $\beta$-glucans from regular and waxy barley. Cereal Chem 77:396-400.

Goode DL, Ulmer HM, Arendt EK. 2005. Model studies to understand the effect of amylase additions and $\mathrm{pH}$ adjustment on the rheological behaviour of simulated brewery mashes. J Inst Brew 111:153-64.

Goupy P, Hugues M, Boivin P, Amiot MJ. 1999. Antioxidant composition and activity of barley (Hordeum vulgare) and malt extracts and of isolated phenolic compounds. J Agric Food Chem 79:1625-34.

Gruppen H, Kormelink FJM, Voragen AGJ. 1993. Water-unxtractable cell wall material from wheat flour. 3. A Structural model for arabinoxylans. J Cereal Sci 18(2):111-28.

Gunkel J, Votez M, Rath F. 2002. Effect of the malting barley variety (Hordeum vulgare L.) on fermentability. J Inst Brew 108:355-61.

Han JY, Schwarz P. 1996. Arabinoxylan composition in barley, malt, and beer. J Am Soc Brew Chem 54:216-20.

Hardwick WA. 1995. Handbook of brewing. New York: Marcel Dekker Inc.

Hassona HZ. 1993. High fibre bread containing brewer's spent grains and its effect on lipid metabolism in rats. Die Nahr 37:576-82.

Henry RJ. 1988. Changes in $\beta$-glucan and other carbohydrate components of barley during malting. J Sci Food Agric 42:333-41.

Hernanz D, Nunez V, Sancho AI, Faulds CB, Williamson G, Bartolome B. 2001. Hydroxycinnamic acids and ferulic acid dehydrodimers in barley and processed barley. J Agric Food Chem 49: 4884-8. 


\section{Barley brewing and by-product applications...}

Holtekjølen AK, Uhlen AK, Knudsen SH. 2007. Barley carbohydrate composition with genetic and abiotic factors. Acta Agric Scand, Sec B-Soil Plant Sci 2:1-8.

Home S, Stenholm K, Wilhelmson A, Autio K. 1999. Properties of starch and cell wall com ponents and their effects on processing. In: Proceedings of 9th Australian Barley Technical Symposium; 2009 September 12-16; Melbourne, Australia. p 2.37.1-2.37.8.

Hoseney RC. 1994. Principles of cereal science and technology. 2nd ed. U.S.A.: American Assn. of Cereal Chemists, Inc. p 179-82.

Hughes PS, Baxter ED. 2001. An overview of the malting and brewing processes. In beer: quality, safety and nutritional aspects. Cambridge, U.K.: The Royal Society of Chemistry. p $1-13$.

Huige NJ. 1994. Brewery by-products and effluents. In: Hardwick WA, editor. Handbook of brewing. New York: Marcel Dekker. p 501-50.

Ishiwaki N, Murayama H, Awayama H, Kanauchi O, Sato T. 2000. Development of high value uses of spent grain by fractionation technology. MBAA Tech Q 37:261-5.

Izydorczyk MS, Biliaderis CG. 1995. Cereal arabinoxylans: advances in structure and physicochemical properties. Carb Poly 28(1):33-48.

Izydorczyk MS, Biliaderis CG. 2007. Arabinoxylans: technologically and nutritionally functional plant polysaccharides. In: Biliaderis CG, Izydorczyk MS, editors. Functional food carbohydrates. Boca Raton: CRC Press, Taylor \& Francis Group. p 249-90.

Izydorczyk MS, Dexter JE. 2008. Barley $\beta$-glucans and arabinoxylans: molecular structure, physicochemical properties, and uses in food products-a review. Food Res Int 41:850-68. Izydorczyk MS, Storsley J, Labossiere D, MacGregor AW, Rossnagel BG. 2000. Variation in total and soluble $\beta$-glucan content in hulless barley: effects of thermal, physical, and enzymic treatments. J Agric Food Chem 48:982-9.

Jacobs D, Meyer K, Kushi L, Folsom A. 1998. Whole-grain intake may reduce the risk of ischemic heart disease death in post-menopausal women: the Lowe Women's Health Study. Am J Clin Nut 66:1264-76.

Jeraci JL, Lewis BA. 1989. Determination of soluble fiber components (1-3,1-4)- $\beta$-D-glucans and pectins. Anim Feed Sci Tech 23:15-25.

Jones BL. 2005a. Endoproteases of barley and malt. J Cereal Sci 42:139-56.

Jones BL. 2005b. The endogenous endoproteinase inhibitors of barley and malt and their roles in malting and brewing. J Cereal Sci 42:271-80.

Jones BL, Budde AD. 2003. The effect of reducing and oxidizing agents and $\mathrm{pH}$ on malt endoproteolytic activities and on malt mashes. J Agri Food Chem 51:7504-12.

Jones BL, Budde AD. 2005. Various malt endoproteinase classes affect wort soluble protein levels. J Cereal Sci 41:95-106.

Kado H, Ishii S, Takoi K, Mitani Y, Shinotsuka K. 1999. Effects of spent grains or their extract on yeast performance. MBAA Tech Q 36:187-90.

Kanauchi O, Agata K. 1997. Protein, and dietary fiber-rich new foodstuff from brewers' spent grain increased excretion of feces and jejunum mucosal protein content in rats. Biosci Biotech Biochem 61:29-33.

Kanauchi O, Mitsuyama K, Araki Y. 2001. Development of a functional germinated barley foodstuff from brewers' spent grain for the treatment of ulcerative colitis. J Am Soc Brew Chem 59:59-62

Kaur VI, Saxena PK. 2004. Incorporation of brewery waste in supplementary feed and its impact on growth in some carps. Biores Techn 91:101-4.

Kawka A, Gorecka D, Gasiorowski H. 1999. The effect of commercial barley flakes on dough characteristic and bread composition. Elec J Pol Agric Univ Food Sci Tech 2(2):521.

Keenan JM, Coulson M, Shamliyan T, Knutson N, Kolberg L, Curry L. 2007. The effects of concentrated barley $\beta$-glucan on blood lipids in a population of hyper cholesterolaemi men and women. Br J Nutr 97:1162-8.

Kissel LT, Prentice N. 1979. Protein and fiber enrichment of cookie flour with brewers' spent grain. Cereal Chem 56:261-6.

Lauro M, Suortti T, Autio K, Linko P, Poutanen K. 1993. Accessibility of barley starch granules to $\alpha$-amylase during different phases of gelatinisation. J Cereal Sci 17(2):125-36.

Leiper KA, Stewart GG, McKeown IP. 2003. Beer polypeptides and silica gel. Part II. Polypeptides involved in foam formation. J Inst Brew 109:73-79.

Lewis MJ, Young TW. 1995. Mashing biochemistry. In: Brewing. 1st ed. Vol. 106. London UK: Chapman \& Hall. $19 \mathrm{p}$

Li J. Kaneko T, Qin LQ, Wang J, Wang Y. 2003. Effects of barley intake on glucose tolerance, lipid metabolism, and bowel function in women. Nutr 19:926-9.

Linko M, Haikara A, Ritala A, Penttila M. 1998. Recent advances in the malting and brewing industry. J Biotech 65:85-98.

Lue S, Hsieh F, Huff HE. 1991. Extrusion cooking of corn meal and sugar beet fiber: effect on expansion properties, starch gelatinization, and dietary fiber content. Cereal Chem 68:227-34.

MacGregor AW, Macri LJ, Schroeder SW, Bazin SL. 1994a. Limit dextrinase from malted barley extraction, purification and characterization. Cereal Chem 71:610-7.

MacGregor AW, Macri LJ, Schroeder SW, Bazin SL. 1994b. Purification and characterization of limit dextrinase inhibitors from barley. J Cereal Sci 20:33-41.

Maillard MN, Berset C. 1995. Evolution of antioxidant activity during kilning: role of insoluble bound phenolic acids of barley and malt. J Agric Food Chem 43:1789-93.

Maillard MN, Soum MH, Boivin P, Berset C. 1996. Antioxidant activity of barley and malt: relationship with phenolic content. Leb Wiss Tech 29:238-44.

Mandalari G, Faulds CB, Sancho AI, Saija A, Bisignano G, Lo Curto R, Waldron KW. 2005 Fractionation and characterization of arabinoxylans from brewers' spent grain and whea bran. J Cereal Sci 42:205-12.

Madhujith T, Shahidi F. 2007. Antioxidative and antiproliferative properties of selected barley cultivars and their potential for inhibition of low-density lipoprotein (LDL) cholestero oxidation. J Agric Food Chem 55:5018-24.

Manners DJ. 1985. Some aspects of the metabolism of starch. Cereal Foods World 30:7227.

Manners DJ, Marshall JJ, Yellowlees D. 1970. The specificity of cereal limit dextrinase. Biochem J 116:539-41.

Marciani L, Gowland PA, Spiller RC, Manoj P, Moore RJ, Young P. 2001. Effect of meal viscosity and nutrients on satiety, intragastric dilution, and emptying assessed by MRI. Am J Physiol Gastrointest Liver Physiol 280:G1227-G1233

Martianez-Tomea M, Murcia A, Frega N, Ruggieri S, Jimea A, Roses F, Parras P. 2004 Evaluation of antioxidant capacity of cereal brans. J Agri Food Chem 52:4690-9.
Mendonca S, Grossmann MVE, Verhe R. 2000. Corn bran as a fibre source in expanded snacks. Leb Wiss Tech 33:2-8.

Mikola J, Pietila K, Enari TM. 1971. The role of malt carboxypeptidases in the liberation of amino acids in mashing. In: Proceedings of the European Brewery Convention Congress, Amsterdam, p 21-28

Miranda MZ, Grossmann MVE, Nabeshima EH. 1994a. Utilization of brewers' spent grain for the production of snacks with fiber. 1. Physicochemical characteristics. Brz Arc Biotech 37:483-93.

Miranda MZ, Grossmann MVE, Prudencioferreira SH, Nabeshima EH. 1994b. Utilization of brewer spent grain (BSG) for production of snacks with fiber. 2. Sensory analysis of snacks. Brz Arc Biotech 37:9-21.

Moll M. 1979. Water in malting and brewing. In: Pollock JRA, editor. Brewing science. Vol. 1. London: Academic Press. p 1-327.

Moonen JHE, Graveland A, Muts GCJ. 1987. The molecular structure of gel protein from barley, its behaviour in wort-filtration and analysis. J Inst Brew 93:125-30.

Morrison WR, Tester RF, Gidley MJ. 1994. Properties of damaged starch granules. II. Crystallinity. J Cereal Sci 19:209-17.

Muller RE. 1991. The effects of mashing temperature and mash thickness on wort carbohydrate composition. J Inst Brew 97:85-92.

Muslin EH, Kanikula AM, Clark SE, Henson CA. 2000. Overexpression, purification, and characterization of a barley $\alpha$-glucosidase secreted by Pichia pastoris. Protein Expr Puri 18:20-26.

Mussatto SI, Dragone G, Roberto IC. 2006. Brewers' spent grain: generation, characteristics and potential application. J Cereal Sci 43:1-14

Mussatto SI, Roberto IC. 2004. Alternatives for detoxification of dilute acid lignocellulosic hydrolyzates for use in fermentative processes: a review. Biores Tech 93:1-10.

Nam SH, Choi SP, Kang MY, Koh HJ, Kozukue N, Friedman M. 2006. Antioxidative activities of bran from twenty one pigmented rice cultivars. Food Chem 94:613-20.

Nascimento RP, Coelho RRR, Marques S, Alves L, Gírio FM, Bon EPS, Amaral-Collaco MT. 2002. Production and partial characterisation of xylanase from Streptomyces sp. strain AMT-3 isolated from Brazilian cerrado soil. Enzy Micro Tech 31:549-55.

Natl. Academy of Sciences. 2002. New eating and physical activity targets to reduce chronic disease risk. Available from: http://www.nationalacademies.org.

Newman CW, McGuire CF. 1985. Nutritional quality of barley. In: Rasmusson DC, editor Barley: Agronomy Monograph No. 26. Madison, WI: American Society of Agronomy, Crop Science Society of America, Soil Science Society of America. p 403-56

Newman CW, Newman RK. 2006. A brief history of barley foods. Cereal Foods World 51(1):4-7.

Newman RK, Newman CW. 1991. Barley as a food grain. Cereal Foods World 36:800-5.

Newman RK, Lewis SE, Newman CW, Boik RJ, Ramag RT. 1989. Hypocholesterolemic effect of barley foods on healthy men. Nutr Rep Intl 39:749-60.

Newman RK, McGuire CF, Newman CW. 1990. Composition and muffin-baking characteristics of flours from four barley cultivars. Cereal Foods World 35:563-6.

Ogushi K, Lim P, Barr AR, Takahashi S, Asakura T, Ito K. 2002. Japanese barley meets Australia: quality performance of malting barley grown in different countries. J Inst Brew 108:303-9.

Okamoto H, Sato K, Yagi N, Inoue M, Yamasaki S, Ishida S, Shibata J. 2002. Development of production process of charcoal bricks from spent grain. Kag Kog Ronb 28:137-42

Okita H, Yamashita H, Yabuuchi S. 1985. Production of microbial enzymes using brewers spent grain. Hakko Kogaku Kaish. J Soc Fermen Tech 63:55-60.

Osman AM, Coverdale SM, Cole N, Hamilton SE, Jersey J, Inkerman PA. 2002. Characterization and assessment of the role of barley malt endoproteases during malt and mashing. I Inst Brew 108:62-67.

Osman AM, Coverdale SM, Onley-Watson K, Bell D, Healy P. 2003. The gel filtration chromatographic-profiles of proteins and peptides of wort and beer: effects of processing malting, mashing, kettle boiling, fermentation and filtering. J Inst Brew 109:41-50.

Ozturk S, Ozboy O, Cavidoglu I, Koksel H. 2002. Effects of brewers' spent grain on the quality and dietary fibre content of cookies. J Inst Brew 108:23-27.

Palmqvist E, Hahn-Hagerdal B. 2000. Fermentation of lignocellulosic hydrolysates. ii. inhibitors and mechanisms of inhibition. Biores Tech 74:25-33.

Peltonen I, Rita H, Aikasalo R, Home S. 1994. Hordein and malting quality in northern barleys. Hereditas 120:231-9.

Perrocheau L, Rogniaux H, Boivin P, Marion D. 2005. Probing heat-stable water-soluble proteins from barley to malt and beer. Proteo 5:2849-58.

Philpott M, Could KS, Lim C, Ferguson LR. 2006. In situ and in vitro antioxidant activity of sweet potato anthocyanins. J Agric Food Chem 54:1710-5.

Pomeranz Y. 1974. Food uses of barley. CRC Crit Rev Food Tech 4:377-94.

Pomeranz Y, Dikeman E. 1976. From barley to beer-a mineral study. Brew Dig 51:30-32.

Prentice N, D'Appolonia BL. 1977. High-fiber bread containing brewers' spent grain. Cereal Chem 54:1084-95.

Psota V, Vejrazka K, Famera O, Hrcka M. 2007. Relationship between grain hardness and malting quality of barley (Hordeum vulgare L.). J Inst Brew 113:80-86.

Quinde Z, Ullrich SE, Baik BK. 2004. Genotypic variation in color and discoloration potential of barley-based food products. Cereal Chem 81:752-8.

Qureshi AA, Burger WC, Peterson DM, Elson CE. 1986. The structure of an inhibitor of cholesterol biosynthesis isolated from barley. J Bio Chem 261:10544-50.

Reinold MR. 1997. Manual pratico de cervejaria. 1st ed. Sao Paulo: Aden Editora e Comunicacoes Ltda. $214 \mathrm{p}$

Roberts RT. 1976. Use of an extract of spent grains as an antifoaming agent in fermentors. Inst Brew 82:96.

Salomonsson AC, Theander O, Aman P. 1980. Composition of normal and high-lysine barley Swed I Agric Res 10:11-16.

Sangeetha PT, Ramesh MN, Prapulla SG. 2004. Production of fructosyl transferase by Aspergillus oryzae CFR 202 in solid-state fermentation using agricultural by-products. Appl Micro Biotech 65:530-7.

Sandberg AS, Andersson H, Kivisto B, Sandstrom B. 1986. Extrusion cooking of high-fibre cereal product. Brit J Nutr 55:245-54

Santos M, Jimenez JJ, Bartolome B, Gomez-Cordovés C, Del-Nozal MJ. 2003. Variability of brewers' spent grain within a brewery. Food Chem 80:17-21. 


\section{CRFSFS: Comprehensive Reviews in Food Science and Food Safety}

Satue-Gracia M, Heinonen IM, Frankel EN. 1997. Anthocyanins as antioxidants on human low-density lipoprotein and lecithin-liposome systems. J Agric Food Chem 45:33627.

Sawadogo L, Sepehri H, Houdebine LM. 1989. Presence of a factor stimulating prolactin and growth hormone secretion in brewers' spent grains. Reprod Nutr Dev 29:139-46.

Schildbach R, Ritter W, Schmithals K, Burbidge M. 1992. New developments in the environmentally safe disposal of spent grains and waste kieselguhr from breweries. Proc Conv - Inst Brew (Asia Pacific Sec) 22:139-43.

Schmitt MR, Marinac L. 2008. Beta-amylase degradation by serine endoproteinases from green barley malt. J Cereal Sci 47:480-8.

Schwarz PB, Han JY. 1995. Arabinoxylan content of commercial beers. J Am Soc Brew Chem 53:157-9.

Shewry PR. 1993. Barley seed proteins. In: MacGregor AW, Bhatty RS, editors. Barley: chemistry and technology. St. Paul, Minn., U.S.A.: American Assn. of Cereal Chemists Inc p 131-97.

Sissons MJ. 1996. Studies on the activation and release of dextrinase in malted barley. J Am Soc Brew Chem 54:19-25.

Skerritt JH, Janes PW. 1992. Disulphide-bonded gel protein aggregates in barley: qualityrelated differences in composition and reductive dissociation. I Cereal Sci 16:219 35.

Slack PT, Wainwright T. 1980. Amylolysis of large starch granules from barleys in relation to their gelatinisation temperatures. J Inst Brew 86(2):74-7.

Slavin J. 2003 Why whole grains are protective: biological mechanisms. Proc Nutr Soc 62:129-34.

Smith MM, Hartley RD. 1983. Occurrence and nature of ferulic acid substitution of cell-wall polysaccharides in graminaceous plants. Carbonhydr Res 118(1):65-80.

Sopanen T, Mikola J. 1975. Purification and partial characterization of barley leucine aminopeptidase. Plant Physiol 55:809-14.

Soulaka AB, Morrison WR. 1985. The amylose and lipid contents, dimension, and gelatinisation characteristics of some wheat starches and their A- and B-granule fractions. J Sci Food Agric 36(8):709-18.

Stewart DC, Freeman G, Evans DE. 2000. Development and assessment of a small-scale wort filtration test for the prediction of beer filtration efficiency. J Inst Brew 106:361-6.
Sun Z, Henson CA. 1991. A quantitative assessment of the importance of barley seed alphaamylase, beta-amylase, debranching enzyme, and alpha-glucosidase in starch degradation. Arch Biochem Biophy 284:298-305.

Swanston JS, Ellis RP, Stark JR. 1995. Effects on grain and malting quality of genes altering barley starch composition. J Cereal Sci 22:265-73.

Tatham AS, Shewry PR. 1995. The S-poor prolamins of wheat, barley and rye. J Cereal Sci 22:1-16.

Tohno-Oka T, Nawada N, Yoshioka T. 2004. Relationship between grain hardness and endosperm cell wall polysaccharides in barley. In: Proceedings of the Ninth Intl. Barley Genetic Symposium, Brno, Czech Republic. p 595-600.

Townsley PM. 1979. Preparation of commercial products from brewer's waste grain and trub. MBAA Tech Q 16:130-4

Ulonska E, Baumer M. 1976. Investigation of the value of water uptake and germination for the estimation of malting quality in barley. In: Gaul H, editor. Proceedings of the $3 \mathrm{rd}$ Intl. Barley Genetics Symposium, Barley Genetics III. Garching. Munchen: Verlag Karl Thiemig. p 579-93.

Ullrich SE, Eslick RF. 1978. Lysine and protein characterization of spontaneous shrunken endosperm mutants of barley. Crop Sci 18:809-12.

Vinkx CJA, Delcour JA, Verbruggen MA, Gruppen H. 1995. Rye water soluble arabinoxylans also vary in their 2-monosubstituted xylose content. Cereal Chem 72(2):227-8.

Voragen AGJ, Schols HA, Marius J, Rombouts FM, Angelino SAGF. 1987. Non-starch polysaccharides from barley: structural features and breakdown during malting. J Inst Brew 93:202-8.

Wang D, Sakoda A, Suzuki M. 2001. Biological efficiency and nutritional value of Pleurotus ostreatus cultivated on spent beer grain. Biores Tech 78:293-300.

Weurding RE, Veldman A, Veen WA, Vander-Aar PJ, Verstegen MW. 2001. In vitro starch digestion correlates well with the rate and extent of starch digestion in broiler chickens. J Nutr 131:2336-42.

Yanniotis S, Petraki A, Soumpasi E. 2007. Effect of pectin and wheat fibers on quality attributes of extruded cornstarch. J Food Eng 80:594-9.

Zielinski H. 2002. Low molecular weight antioxidants in the cereal grain: a review. Pol Food Nutr Sci 11(52):3-9. 